\title{
PENGARUH KONSENTRASI TEMBAGA TERBAIK UNTUK PERTUMBUHAN DAN PRODUKSI DUA VARIETAS MELON (Cucumis melo L.) PADA SISTEM HIDROPONIK MEDIA PADAT
}

\author{
Yunita Sekar Kartika, Yohannes Cahya Ginting \& Agus Karyanto \\ Jurusan Agroteknologi, Fakultas Pertanian Universitas Lampung \\ Jl. Prof. Dr. Soemantri Brodjonegoro no. 1 Bandar Lampung 35145 \\ Email: yunitasekarkartika@ymail.com
}

\begin{abstract}
ABSTRAK
Melon (Cucumis melo L.) merupakan tanaman hortikultura dari famili Cucurbitaceae. Potensi ekonomi tanaman hortikultura khususnya buah melon sangat besar. Selain pangsa pasar yang masih luas, harga jualnya relatif tinggi, dan jangka waktu untuk produksinya relatif singkat. Penanganan yang dianggap efektif dalam meningkatkan pertumbuhan dan produksi buah melon yaitu membudidayakan tanaman melon dengan cara metode hidroponik yang dilakukan di rumah kaca.Penelitian ini dilaksanakan di Rumah Plastik Laboratorium Lapangan Terpadu Fakultas Pertanian Universitas Lampung pada bulan Juli Oktober 2013. Penelitian ini menggunakan metode penelitian yang digunakan adalah Rancangan Acak Kelompok Lengkap (RAKL). Perlakuan disusun secara faktorial $2 \times 5$ dengan 3 kali ulangan pola faktorial yang terdiri dari 2 faktor. Faktor pertama adalah perlakuan konsentrasi tembaga $(\mathrm{Cu})$ yaitu: $\mathrm{Cu} 1=0,01 \mathrm{ppm}, \mathrm{Cu} 2=0,05 \mathrm{ppm}, \mathrm{Cu} 3=0,09 \mathrm{ppm}, \mathrm{Cu} 4=0,13 \mathrm{ppm}$, dan $\mathrm{Cu} 5=$ $17 \mathrm{ppm}$. Faktor kedua adalah varietas tanaman melon $(\mathrm{V})$, yaitu $\mathrm{v}_{1}=$ varietas Action dan $\mathrm{v}_{2}=$ varietas Aramis.Homogenitas ragam diuji dengan uji Bartlett dan aditivitas data diuji dengan menggunakan uji Tukey. Jika asumsi terpenuhi, data dianalisis dengan sidik ragam dan dilanjutkan dengan uji ortogonal kontras polinomial pada taraf $5 \%$. Hasil penelitian ini menunjukkan bahwa pertumbuhan melon varietas Action lebih baik daripada varietas Aramis, sedangkan pada produksi buah melon varietas Aramis lebih baik dari pada varietas Action. Bobot buah rata-rata varietas Aramis 4,15 gram atau selisih 0,28\%. Produksi varietas Aramis tidak berbeda dengan produksi varietas Action, respons tanaman terhadap konsentrasi $\mathrm{Cu}$ antara 0,01-0,17 ppm masih linier sehingga belum diperoleh konsentrasi $\mathrm{Cu}$ maksimum. Setiap kenaikan 0,04 ppm $\mathrm{Cu}$ bobot buah meningkat 0,01 gram, terjadi interaksi antara konsentrasi $\mathrm{Cu}$ terhadap varietas melon pada variabel pengamatan bobot kering brangkasan, volume buah dan ketebalan daging tetapi tidak ada interaksi antara varietas dan konsentrasi $\mathrm{Cu}$ terhadap bobot buah buah melon.
\end{abstract}

Kata kunci: Hidroponik, konsentrasi tembaga, melon, varietas Action, varietas Aramis.

\section{PENDAHULUAN}

Melon (Cucumis melo L.) merupakan tanaman hortikultura dari famili Cucurbitaceae. Melon memiliki kandungan gizi yang cukup tinggi. Kandungan zat gizi dalam 100 gram buah melon dari bagian yang dapat dimakan mengandung energi $23 \mathrm{kal}$, protein 0,6 gram, kalsium $17 \mathrm{mg}$, vitamin A $2.400 \mathrm{IU}$, vitamin C $30 \mathrm{mg}$, thiamin $0,045 \mathrm{mg}$, ribovalin $0,065 \mathrm{mg}$, niacin $1,0 \mathrm{mg}$, karbohidrat $6,0 \mathrm{mg}$, besi $0,4 \mathrm{mg}$, nicotinamida $0,5 \mathrm{mg}$, air 93,0 ml, serat 0,4 gram (Tjahjadi, 1992).

Hidroponik merupakan salah satu metode penanaman tanaman yang sangat produktif dan efisien, ramah lingkungan dan dapat digunakan untuk memperbaiki lingkungan. Sistem hidroponik banyak digunakan untuk tanaman hortikultura seperti melon. Pada awalnya, sistem hidroponik identik dengan penanaman tanpa media tanah. Dengan perkembangan teknologi, hidroponik tidak hanya menggunakan media air, tetapi juga dengan media agregat dan udara. Namun, prinsipnya tetap berdasarkan bahwa media tidak menyediakan unsur hara bagi tanaman. Semua kebutuhan hara tanaman diberikan melalui larutan hara (Lingga, 1984).

Fungsi penting tembaga adalah sebagai aktivator dan membantu kelancaran proses fotosintesis untuk terbentuknya klorofil atau membawa beberapa enzim. Klorofil adalah pigmen pemberi warna hijau pada tumbuhan, alga dan bakteri fotosintetik. Pigmen ini berperan dalam proses fotosintesis tumbuhan dengan menyerap dan mengubah energi cahaya menjadi energi kimia (Karma, 2004). Tembaga $(\mathrm{Cu})$ mempunyai peranan penting dalam pembentukan hijau daun (khlorofil). Klorofil adalah pigmen hijau daun pada tumbuhan yang 
mengandung $\mathrm{Fe}$ atau $\mathrm{Mg}$ yang sangat berperan dalam fotosintesis. Tanaman tingkat tinggi mempunyai dua macam klorofil yaitu klorofil a $\left(\mathrm{C}_{55} \mathrm{H}_{72} \mathrm{O}_{5} \mathrm{~N}_{4} \mathrm{Mg}\right)$ yang berwarna hijau tua dan klorofil b $\left(\mathrm{C}_{55} \mathrm{H}_{70} \mathrm{O}_{6} \mathrm{~N}_{4} \mathrm{Mg}\right)$ yang berwarna hijau muda. Klorofil a dan klorofil $b$ paling kuat menyerap cahaya di bagian merah $(600-700 \mathrm{~nm})$, dan paling sedikit menyerap cahaya hijau $(500-600 \mathrm{~nm})$ (Hendriyani dan Setiari, 2009). Data mengenai konsentrasi $\mathrm{Cu}$ dalam larutan hara untuk tanaman melon, khususnya di dataran rendah seperti di Lampung belum banyak diketahui.

Pada penelitian ini varietas melon yang digunakan adalah varietas Action dan Aramis. Penelitian ini bertujuan untuk mengetahui perbedaan pengaruh konsentrasi $\mathrm{Cu}$ terhadap pertumbuhan dan produksi melon, mengetahui perbedaan pertumbuhan dan produksi melon antara varietas Aramis dan varietas Action, dan mengetahui adanya respon yang berbeda dari setiap varietas Aramis dan varietas Action terhadap konsentasi $\mathrm{Cu}$.

\section{BAHAN DAN METODE}

Penelitian ini telah dilaksanakan di Rumah Plastik Laboratorium Lapangan Terpadu Fakultas Pertanian Universitas Lampung dari bulan Juli sampai bulan Oktober 2013. Bahan-bahan yang digunakan dalam penelitian ini adalah arang sekam, benih melon hibrida varietas Action dan varietas Aramis, pupuk NPK mutiara, urea, kalsium klorida, magnesium sulfat, besi sulfat, mangan sulfat, asam boraks, tembaga sulfat, seng sulfat, natrium molibdat, aquades.

Metode penelitian yang digunakan adalah Rancangan Acak Kelompok Lengkap (RAKL). Perlakuan disusun secara faktorial 2 x 5 dengan 3 kali ulangan sehingga jumlah satuan percobaan ada sebanyak 30 satuan percobaan. Setiap satuan percobaan terdiri dari satu tanaman.Faktor pertama adalah varietas melon yaitu varietas Action dan varietas Aramis. Faktor kedua adalah perlakuan konsentrasi unsur hara Tembaga $(\mathrm{Cu})$ yaitu $0,01 \mathrm{ppm}, 0,05 \mathrm{ppm}, 0,09 \mathrm{ppm}, 0,13 \mathrm{ppm}$, dan 0,17 ppm. Homogenitas ragam diuji dengan menggunakan uji Bartlett dan aditivitas data diuji dengan menggunakan uji Tukey.Jika asumsi terpenuhi, data analisis dengan sidik ragam dan dilanjutan dengan uji ortogonal kontras polinomial.

Benih melon yang telah disemai berumur tujuh hari dipindahkan ke dalam polybag yang berisi media arang sekam. Penyiraman dilakukan 3-4 kali sehari dengan larutan hara yang telah terdapat unsur tembaga, dengan konsentrasi tembaga $(\mathrm{Cu})$ sesuai perlakuan $(0,01$ ppm, 0,05ppm, 0,09 ppm, 0,13 ppm, dan 0,17 ppm), tiap penyiraman 300-400 $\mathrm{ml}$ per tanaman. Penyiraman dilakukan selama 60 hari setelah pindah tanam. Dosis atau kebutuhan $\mathrm{Cu}$ selama penelitian adalah pada konsentrasi $0,01 \mathrm{ppm}$ sebanyak 168 gram per tanaman, $0,05 \mathrm{ppm}$ sebanyak 840 gram per tanaman, $0,09 \mathrm{ppm}$ sebanyak 1470 gram per tanaman, 0,13 ppm sebanyak 2100 gram per tanaman, dan pada $0,17 \mathrm{ppm}$ sebanyak 2660 gram per tanaman. Variabel yang diamati adalah panjang tanaman, jumlah daun, bobot kering tanaman, jumlah bunga betina, volume buah, diameter buah, ketebalan daging buah, bobot buah, kadar brix buah.

\section{HASIL DAN PEMBAHASAN}

Hasil penelitian menunjukkan bahwa pertumbuhan vegetatif tanaman melon varietas Action lebih baik daripada varietas Aramis yang ditunjukan oleh variabel panjang tanaman dan jumlah daun. Pada pertumbuhan generatif(jumlah bunga betina) dan produksi buahmelon terlihat pada varietas Aramis lebih baik dibandingkan varietas Action yang ditunjukan pada variabel bobot buah, volume buah, diameter buah, ketebalan daging buah dan kadar brix buah serta variabel bobot berangkasan tanaman melon.

Interaksi antara varietas melon dengan konsentrasi tembaga terjadi pada pengamatan bobot kering brangkasan (gambar 1), volume buah (gambar 2) dan ketebalan daging buah (gambar 3). Interaksi antara varietas dengan konsentrasi $\mathrm{Cu}$ ada kaitannya sehingga dapat meningkatkan bobot kering brangkasan, volume buah dan ketebalan daging buah. Konsentrasi $\mathrm{Cu}$ yang berperan terhadap aktivitas fotosintesis yang berjalan dengan lancar yang diharapkan pertumbuhan dan produksinya baik. Hubungan antara varietas melon responsif terhadap pemberian konsentrasi $\mathrm{Cu}$. Sedangkan interaksi yang tidak nyata terdapat pada pengamatan panjang tanaman, jumlah daun, jumlah bunga betina, bobot buah, diameter buah dan kadar brix buah. Hal ini mungkin karena pada kisaran konsentrasi tersebut respons kedua varietas masih sama.

Respons kedua varietas sama terhadap tembaga meskipun setiap varietas memiliki genotipe yang berbeda-beda, genotipe ini nantinya akan menghasilkan fenotipe yang berbeda. Genotipe suatu varietas tanaman menentukan kemampuan menghasilkan, adaptasi regional dan ketahanan terhadap hama/ penyakit dan mutu. Selain genotipe, faktor lingkungan tempat tumbuhnya juga dapat menyebabkan sifat- sifat yang beragam dari suatu tanaman hortikultura. Misalnya suatu varietas yang mempunyai kemampuan menghasilkan produksi tinggi tetapi jika kebutuhan air dan hara tidak terpenuhi serta gulma tidak dikendalikan, maka varietas 


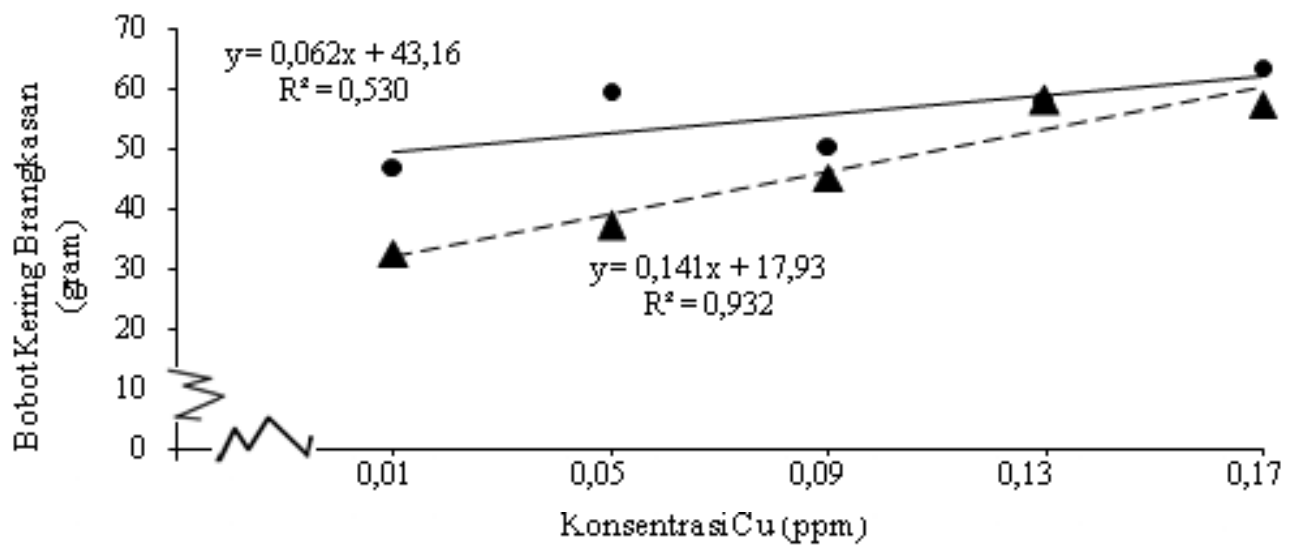

Gambar 1. Hubungan antara konsentrasi tembaga dan bobot kering tanaman melon. $\mathrm{v}_{1}(\boldsymbol{\Delta})=$ varietas Action, $\mathrm{v}_{2}(\bullet)=$ varietas Aramis, $\mathrm{ppm}=\mathrm{gram} / \mathrm{L}$.

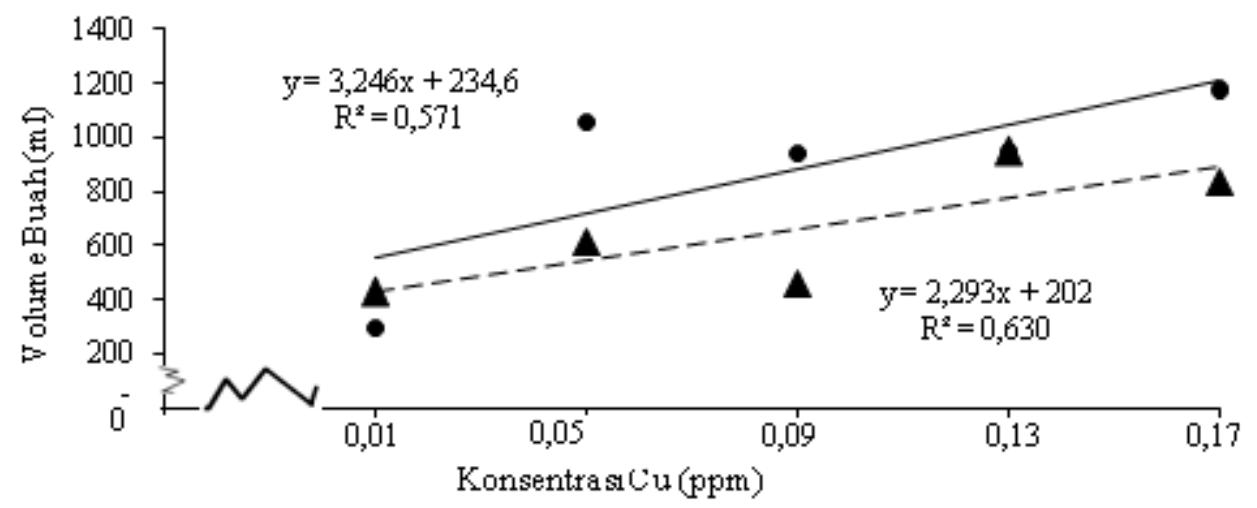

Gambar 2. Hubungan antara konsentrasi tembaga dan volume buah melon. $\mathrm{v}_{1}(\boldsymbol{\Delta})=$ varietas Action, $\mathrm{v}_{2}(\bullet)=$ varietas Aramis, $\mathrm{ppm}=\mathrm{gram} / \mathrm{L}$.

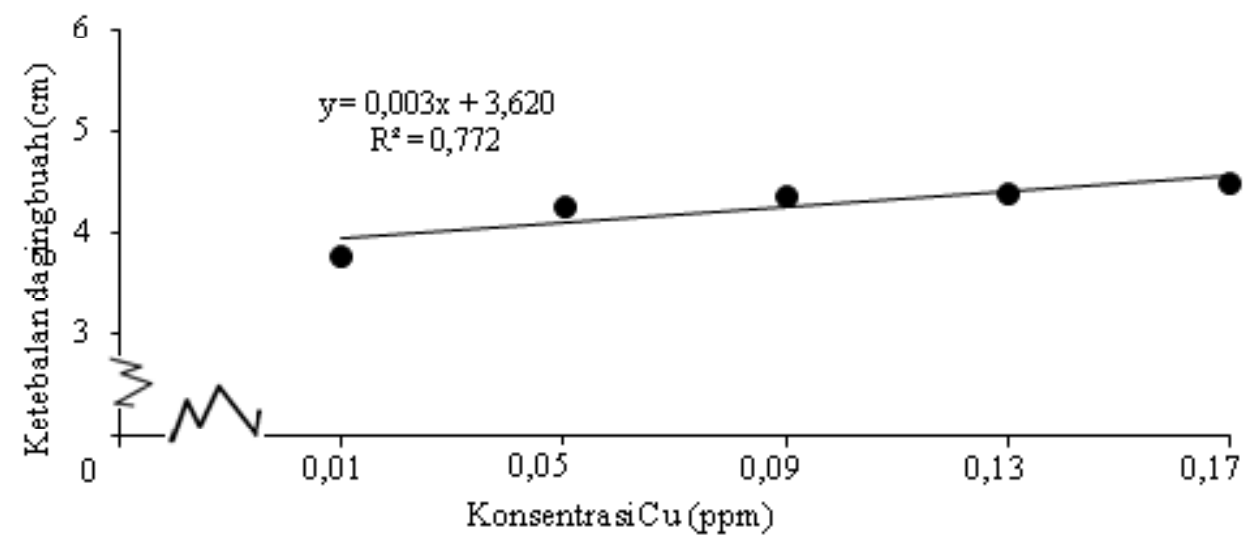

Gambar 3. Hubungan antara konsentrasi tembaga dan ketebalan daging buah melon.

itu tidak dapat memberikan hasil yang tinggi dan sebaliknya jika genotype suatu varietas untuk menghasilkan rendah maka sebaik apapun lingkungannya tidak mampu membuat varietas tersebut berproduksi tinggi (Pratignja dan Wartoyo, 2006). Dalam deskripsi produk dari Tim Bina Karya Tani dan PT. East West Seed Indonesia (2009) selaku perusahaan yang memproduksi benih melon varietas Action dan varietas 
Aramis, buah melon varietas Action memiliki bobot 2,1 - 4,0 kg dan varietas Aramis 2,2 - 2,8 kg sehingga mendukung hasil penelitian yang menunjukkan bahwa varietas Aramis memiliki bobot, volume, dan ketebalan daging buah yang lebih besar dibandingkan varietas Action. Namun bobot melon yang dihasilkan dari varietas Action dan varietas Aramis tidak ada satupun yang mencapai bobot sesuai deskripsi dari masing-masing varietas. Bobot buah melon hasil penelitian pada varietas Action 1,2 - 1,7 kg sedangkan untuk varietas Aramis yaitu $1,2-1,6 \mathrm{~kg}$.

Hasil penelitian juga memperlihatkan bahwa pada pemberian tembaga dengan konsentrasi $0,01-0,17 \mathrm{ppm}$ untuk melon varietas Action secara nyata meningkatkan secara linier panjang tanaman. Bobot kering brangkasan, jumlah bunga betina, bobot buah, volume buah, diameter buah, ketebalan daging buah meningkat secara nyata untuk melon varietas Aramis. Peningkatan yang terjadi pada variabel pengamatan masih linier sehingga konsentrasi tembaga yang diberikan belum mencapai titik maksimum. Namun pada jumlah daun dan kadar brix buah melon var. Action dan Aramis secara nyata mengalami penurunan. Pada bobot kering tanaman, volume buah dan ketebalan daging buah berpengaruh nyata pada melon varietas Action dan Aramis. Sedangkan pada panjang tanaman, jumlah daun, jumlah bunga betina, bobot buah, diameter buah dan kadar brix buah tidak berpengaruh nyata pada melon varietas Action dan Aramis.

Dari data pengamatan bobot buah melon, bobot buah melon yang dihasilkan tidak sesuai standar ini karena penyakit fisiologis getah merah. Pada semua buah melon yang dihasilkan baik varietas Action maupun Aramis terlihat dengan jelas terjadi getah merah pada batang tanaman. Getah merah muncul di bagian batang tanaman pada semua tingkatan tembaga yang diberikan ke tanaman melon dari yang terendah $0,01 \mathrm{ppm}$ hingga yang tertinggi $0,17 \mathrm{ppm}$. Getah merah juga dapat terjadi akibat tanaman mengalami stres. Stres tanaman dapat terjadi karena kelembaban udara yang rendah, garam larut berlebihan dalam media tanam, tingginya tingkat transpirasi, dan kelembaban tanah tinggi sehingga menyebabkan aerasi akar kurang dan mengakibatkan kurangnya oksigen (Dwidjoseputro,1989).

Serangan penyakit diduga terjadi karena rumah plastik yang digunakan tidak memenuhi standar ideal rumah plastik sehingga penyakit mudah menyerang tanaman melon. Pengendalian secara mekanik dan kimiawi telah dilakukan untuk mencegah penyakit namun tetap saja terjadi kehilangan hasil dan penurunan mutu melon yang dihasilkan.
Dilihat dari kondisi lingkungan pada saat penanaman (Agustus - Oktober) pada saat itu suhu udara tinggi sehingga transpirasi pada tanaman melon juga tinggi ditambah lagi pada saat penanaman hanya dilakukan tiga kali penyiraman secara manual (disiram sendiri oleh peneliti). Penyiraman manual dipilih karena tidak ada listrik di rumah plastik tempat penanaman tanaman melon. Namun penyiraman manual yang dilakukan juga memiliki kekurangan yaitu ketidaktepatan waktu penyiraman dan sedikitnya intensitas penyiraman dalam sehari sehingga mempengaruhi kelembaban media tanam.

Rendahnya produksi dalam percobaan ini sangat dipengaruhi oleh faktor lingkungan.Salah satunya diduga karena suhu lingkungan terlalu tinggi.Suhu lingkungan pada suatu percobaan berkisar $36-42{ }^{\circ} \mathrm{C}$ dan pada minggu ke-5 seharusnya berkisar $44-45^{\circ} \mathrm{C}$. Pada suhu di rumah plastik berkisar dari $32-45^{\circ} \mathrm{C}$, sedangkan untuk suhu tanaman melon membutuhkan suhu rata-rata berkisar dari $18-35^{\circ} \mathrm{C}$ dan akan tumbuh dengan optimal pada suhu $22-30^{\circ} \mathrm{C}$ (Djaenudin et al. 2000).

Sehingga pada penelitian ini suhu yang tinggi juga menyebabkan transpirasi tinggi sehingga respirasi meningkat. Akibatnya terjadi penguraian fotosintesis untuk menghasilkan energi menurun, aktivitas enzim pada proses fotosintesis terganggu sehingga hasil fotosintat menurun. Suhu udara yang terlalu tinggi dapat mempengaruhi serapan unsur hara, respirasi, menyebabkan tanaman layu, pada keadaan ekstrim dapat mati, karena laju kehilangan air (transpirasi) absorbsi air oleh akar, mempengaruhi pembungaan dan pembuahan yaitu gagalnya penyerbukan bunga karena mengeringnya tepung sari (Thompson dan Kelly, 1957).

Peningkatan bobot buah yang dihasilkan diikuti dengan peningkatan volume, diameter, dan ketebalan daging buah yang dihasilkan namun peningkatan bobot buah tidak diikuti peningkatan kadar brix buah. Hal ini diduga karena terjadi pelebaran daging buah yang didukung oleh elastisitas kulit buah melon sehingga meskipun bobot buah, volume, diameter dan ketebalan daging buah meningkat namun kadar brix buah tersebut menurun. Bobot buah yang dihasilkan rata-rata varietas Aramis 4,15 gram atau 0,28\%. Produksi varietas Aramis tidak berbeda dengan produksi varietas Action.

Penelitian ini menggunakan unsur hara mikro yaitu Tembaga $(\mathrm{Cu})$ yang dapat diterapkan oleh masyarakat karena dapat meningkatkan bobot buah per tanaman melon setiap kenaikan 0,04 ppm atau dosis gram per liter $\mathrm{Cu}$ bobot buah meningkat 0,01 gram. Respons volume buah terhadap konsentrasi Cu sampai 0,17 ppm masih linier. Pada varietas Aramis setiap peningkatan konsentrasi $\mathrm{Cu} 0,05 \mathrm{ppm}$ volume buah meningkat 0,20 
$\mathrm{ml}$. Pada varietas Action setiap peningkatan konsentrasi $\mathrm{Cu} 0,04$ ppm volume buah meningkat $0,01 \mathrm{ml}$, pada kedua varietas tersebut yang lebih unggul yaitu varietas Aramis (Gambar 2). Bercocok tanam secara hidroponik sudah banyak dipakai oleh beberapa masyarakat untuk memanfaatkan lahan yang tidak terlalu luas. Banyak keuntungan dan manfaat yang dapat diperoleh dari sistem hidroponik. Sistem ini dapat menguntungkan petani dalam meningkatkan kualitas dan kuantitas hasil pertaniannya dan juga dapat memaksimalkan lahan pertanian yang ada karena tidak membutuhkan lahan yang banyak sehingga penelitian tentang hidroponik ini dapat diterapkan oleh masyarakat.

\section{KESIMPULAN}

Berdasarkan hasil penelitian yang telah dilaksanakan dapat diperoleh kesimpulan pertumbuhan melon varietas Action lebih baik daripada varietas Aramis, sedangkan pada produksi buah melon varietas Aramis lebih baik dari pada varietas Action. Bobot buah rata-rata varietas Aramis 4,15 gram atau 0,28\%. Produksi varietas Aramis tidak berbeda dengan produksi varietas Action. Respons tanaman terhadap konsentrasi $\mathrm{Cu}$ antara 0,01-0,17 ppm masih linier sehingga belum diperoleh konsentrasi $\mathrm{Cu}$ maksimum. Setiap kenaikan $0,04 \mathrm{ppm}$ atau setara 672 gram per tanaman bobot buah meningkat 0,01 gram. Pada konsentrasi 0,01 ppm bobot kering tanaman varietas Aramis lebih baik dari varietas Action sebesar 6,01 gram atau 9,95\% begitu pada konsentrasi 0,17 ppm pada varietas Aramis sama dengan vareitas Action. Dosis atau kebutuhan $\mathrm{Cu}$ selama penelitian adalah pada konsentrasi $0,01 \mathrm{ppm}$ sebanyak 168 gram per tanaman, 0,05 ppm sebanyak 840 gram per tanaman, 0,09 sebanyak 1.470 gram per tanaman, 0,13 ppm sebanyak 2.100 gram per tanaman, dan pada 0,17 sebanyak 2.660 gram per tanaman.

\section{SANWACANA}

Ucapan terima kasih disampaikan kepada Dr.Ir. Darwin H. Pangaribuan, M.Sc., yang telah membantu memberikan ide, bimbingan, motivasi, arahan, dan saran selama penelitian sampai penyelesaian skripsi ini dengan penuh kesabaran.

\section{DAFTAR PUSTAKA}

Benton J, J. 2005. Hidroponic : a Practical Guide for The Soilless Grower. CRC Press. Boca Raton, London.
Djaenudin D, H. Marwan, H. Subagyo, A. Mulyani dan N. Suharta. 2000. Kriteria Kesesuaian Lahan untuk Komoditas Pertanian. Pusat Penelitian Tanah dan Pengembangan Agroklimat. Badan Penelitian dan Pengembangan Pertanian. Departemen Pertanian. Bogor.

Dwidjoseputro, D. 1989. Pengantar Fisiologi Tumbuhan. PT. Gramedia. Jakarta. Hal: 66-105.

Jakarta. 1994. Pigmen Klorofil. Erlangga.

Faust, M.B dan N.E. Christians. 2000. Copper Reduces Shoot Growth and Root Development of Creeping Bentgrass. Published in Crop Sci. 40 (3) : 498502.

Hendriyani, I. S dan N. Setiari. 2009. Kandungan Klorofil dan Pertumbuhan Kacang Panjang (Vignasinensis) pada Tingkat Penyediaan Air yang Berbeda. J.Sains\& Mat. 17(3): 145-150.

Isnaini. 2007. Evaluasi Karakteristik Hortikultura Hibrida Melon (Cucumis melo L). Introduksi dan Hasil Rakitan Pusat Kajian Buah - Buahan Tropika (PKBT). IPB. Bogor.

Karma, E. 2004. Pemanfaatan Limbah Cair Pabrik Monosodium Glutamat sebagai Pupuk Tanaman Melon (Cucumis melo L). Purwokerto. Agritek. 14 (1) : 61-64.

Lingga, P. 1984. Hidroponik Bercocok Tanam Tanpa Tanah. Penebar Swadaya. Jakarta. Hal : 4-13.

Makmur, A. 1992. Pengantar Pemuliaan Tanaman. Rineka Cipta. Jakarta. Hal :11.

Nuraini, N. 2007. Perlindungan Hak Milik Intelektual Varietas Tanaman (Guna Peningkatan Daya Saing Agribisnis. Alfabeta. Bandung. Hal. 81.

PT. East west Seed Indonesia. 2009. http:// www.eastwestindo.com/products.php. Diakses pada tanggal : 10 November 2013.

Pratignja dan Wartoyo. 2006. Dasar Hortikultura. Universitas Sebelas Maret. Surakarta.

Schwarz, G dan R. R. Mendel. 2006. Cuprumcofaktor biosynthesis and cuprumenzymmes, Annu. Rev. Plant Biol. 57: 623-647.

Thompson, H. C. dan W. C. Kelly. 1957. Vegetable Crops. McGraw-Hill Book Co. New York. 422p.

Tjahjadi, Nur. 1987. Bertanam Melon. Jakarta: Kanisius. 
Wijayani A, dan W. Widodo. 2005. Usaha meningkatkan kualitas beberapa varietas tomat dengan sistem budidaya hidroponik. Ilmu Pertanian. 12(1): 7783. 